\title{
Gaseous emissions monitoring and ash analysis of an industrial incinerator in Pakistan
}

\author{
Sana Akhtar ${ }^{1,}$, , Sunaina Ashfaq ${ }^{1}$, Asim Mehmood ${ }^{2}$, Saamia Saif ${ }^{2}$, Almas Hamid $^{1}$ \\ ${ }^{1}$ Kinnaird College for Women, Lahore, Pakistan \\ ${ }^{2}$ Global Environmental Laboratories, Lahore, Pakistan
}

Email address:

sanakhtar23@gmail.com(S. Akhtar), ishfaq.naina@gmail.com(S. Ashfaq), asim@eco-intl.org(A. Mehmood), Saamia@eco-intl.org(S. Saif), almas209@yahoo.com(A. Hamid)

\section{To cite this article:}

Sana Akhtar, Sunaina Ashfaq, Asim Mehmood, Saamia Saif, Almas Hamid. Gaseous Emissions Monitoring and Ash Analysis of an Industrial Incinerator in Pakistan. International Journal of Environmental Monitoring and Analysis. Vol. 1, No. 4, 2013 , pp. $128-132$. doi: 10.11648/j.ijema.20130104.13

\begin{abstract}
A study was conducted on an industrial incinerator located at Kala Shah Kaku, Punjab, Pakistan to monitor and evaluate stack emissions $\left(\mathrm{NO}_{\mathrm{X}}, \mathrm{SO}_{\mathrm{X}}, \mathrm{CO}, \mathrm{VOC}_{\mathrm{S}}\right)$ and determination of heavy metals in bottom and fly ash of an industrial incinerator burning tobacco dust. Incinerated bottom and fly ash samples were collected. For the purpose of ambient air monitoring three different sides of incinerator were selected. The air emissions monitoring included emissions from right side of the incinerator (A1), emissions from left side of the incinerator (A2) and emissions from the main gate of the incinerator (A3). To determine heavy metals in bottom and fly ash, HACH and Merck procedure via spectrophotometer were used. Respirable Dust Sampler and Flue Gas Analyzer were used to monitor ambient air quality and stack emissions respectively. The results of ambient quality ( $\mathrm{SOx}, \mathrm{NOx}, \mathrm{CO}, \mathrm{CO}_{2}, \mathrm{PM} \& \mathrm{O}_{2}$ ) revealed that the emissions from $\mathrm{A} 2$ were comparatively higher than emissions from A1 and A3. With the help of Flue Gas Analyzer it was found that carbon monoxide (CO) emissions were higher than $\mathrm{SO}_{\mathrm{X}}, \mathrm{NO}_{\mathrm{X}}$ and $\mathrm{VOC}_{\mathrm{S}}$. Bottom ash analysis by spectrophotometer showed that the heavy metals were below the detectable limits. The analysis conducted for heavy metals in fly ash by spectrometry as well confirmed that lead $(\mathrm{Pb})$ and cadmium $(\mathrm{Cd})$ were below the detectable limits and chromium was $1.96 \mathrm{mg} / \mathrm{kg}$ of the ash.
\end{abstract}

Keywords: Incineration, Tobacco, Ambient Air, Stack Emissions, Fly and Bottom Ash, Heavy Metals

\section{Introduction}

\subsection{Incineration}

Incineration is a waste treatment process of converting waste into ashes, flue gases and heat [1]. The process of incineration aims at reducing the volume, the toxicity and the reactivity of the waste and is thus a viable management strategy throughout the world for treating the increasing combustible municipal solid waste (MSW) that cannot be recycled $[2,3]$.

Concern has been raised in recent years over the environmental and health related impacts of incineration as this process leads to the emissions of trace quantities of metals and polychlorinated dibenzo -p-dioxins $\left(\mathrm{PCDD}_{\mathrm{S}}\right)$ and dibenzo furans $\left(\mathrm{PCDF}_{\mathrm{S}}\right)$, as well as other emissions [48]. Although incineration of MSW reduces greatly the volume (by about $90 \%$ ), the mass (by about $75 \%$ ) of MSW and provides energy but it cannot be considered the final solution of managing MSW [3, 9].
Incineration generates roughly $17 \mathrm{Mt}$ of solid residues per year world-wide and it is estimated that this amount would be doubled within the next decade. It is very important that it is disposed in an environmentally acceptable manner $[9,10]$. Moreover, the advancements in air pollution control measures in municipal solid waste incineration (MSWI) has shifted the constituents of concern from air emissions to the solid residues $[11,12]$.

Heavy metals (after undergoing gasification, oxidation, chlorination, condensation, coagulation, and nucleation), from the raw wastes, are condensed into incinerated residues and thus have a potential to impact the environment [13]. During MSWI, lithophilic metals such as $\mathrm{Fe}, \mathrm{Cu}, \mathrm{Cr}$, and $\mathrm{Al}$ remain mainly in the bottom ash (BA) while $\mathrm{Cd}$ is volatilized and condensed to the fly ash. About two thirds of $\mathrm{Pb}$ and $\mathrm{Zn}$ were found in the bottom ash despite their high volatility [14]. Bottom ash represents about $80 \%$ of the residues and contains various substances that may pose a threat to the environment [10]. Decision making on the utilization, treatment or disposal of such 
residues requires the evaluation of the environmental quality [12].

Chemical composition, mineralogical characteristics, and heavy metals leaching behaviors of municipal solid waste incineration bottom ash (MSWIBA) were the focused areas in most of the studies conducted during the last decade [2, $9,12-13,15-16]$ but the issue of toxicological consequences of MSWIBA has been limited to a few studies $[17,18]$. Despite rapid improvement in the analytical techniques in the recent past, there is a huge lack in the quantitative evaluation of the risk of a mixture of compounds (such as Bottom Ash) [18].

\subsection{Study Area}

One of the main commercial incinerators of Pakistan is located near Lahore and is approved by relevant Environment Protection Agency. It has handled over $400,000 \mathrm{kgs}$ of different types of industrial hazardous waste and non hazardous wastes up till now. The wastes include raw and damaged materials, sludge from treatment plants, diapers, pesticides, plastic bottles, paints, tobacco dust and some expired goods etc [19]. During the present study the waste for incineration at the plant was tobacco dust of a leading Tobacco Company.

\section{Methods}

Composite sampling procedure was adopted to collect samples of tobacco bottom and fly ash.

\subsection{Procedures for Heavy Metal Determination in Bottom Ash}

Merckoquant Lead Test Kit and Spectroquant Nova 60 Spectrophotometer were used to determine lead concentrations in the bottom ash samples. $0.5 \mathrm{ml}$ of reagent $\mathrm{Pb} 1$ and $\mathrm{Pb} 2$ was pipette out into a test tube along with 8 $\mathrm{ml}$ of pretreated sample. Sample was filled into the cell and was measured in the photometer.

For the determination of cadmium concentration in the bottom ash sample, Merckoquant Cadmium test Kit and Spectroquant Nova 60 Spectrophotometer were used. $5 \mathrm{ml}$ of pre treated sample was pipette out and $0.20 \mathrm{ml}$ of $\mathrm{Cd} 1$ reagent and 1 level green micro spoon was added into reaction cell and closed tightly. The cell was shaked vigorously until the reagent was completely dissolved. It was left for 2 minutes to stand and the sample was measured in the photometer.

For the determination of chromium total concentration in the bottom ash sample, HACH procedure was used. $25 \mathrm{ml}$ of sample was taken in $25 \mathrm{ml}$ square sample cell. Content of one chromium 1 reagent powder pillow was added and swirled to mix. Sample cell cap was kept off. Prepared sample was placed into a boiling water bath. The timer was pressed to be okay for 5 minutes. At the reaction timer of expiration, the prepared sample was removed. Running water was used to cool the square sample cell to $25^{\circ} \mathrm{C}$.
Then cap was removed. The contents of one chromium 2 reagent powder pillow was added and swirled to mix. Sample cell was then closed and was inverted to mix. The timer was pressed to be okay for 5 minutes reaction time period. During the reaction time $10 \mathrm{ml}$ from the mixing bottle into a square sample cell was poured. Blank cell holder was wiped for zeroing. After zeroing, the sample was inserted into cell holder for reading. Reading on the display was noted $[20,21]$.

\subsection{Determination of Heavy Metals in Tobacco Fly Ash}

5 gram of ash sample was taken. $75 \mathrm{ml}$ of 1:1 ratio of $\mathrm{HNO}_{3}$ was prepared and was placed on the hot plate. When volume of sample was remained up to $15 \mathrm{ml}$ it was filtered and its $\mathrm{pH}$ was maintained up to 3-4 with $\mathrm{NaOH}$ or $\mathrm{HNO}_{3}$. After maintaining $\mathrm{pH}$ the volume of $75 \mathrm{ml}$ with distilled water was prepared.

\subsubsection{Use Digested Sample for Heavy Metals Analysis}

A test tube was taken. At $515 \mathrm{~nm}, 0.5 \mathrm{ml}$ of $\mathrm{Pb}-1$ and $\mathrm{Pb}$ 2 reagent and $8 \mathrm{ml}$ of digested sample was added in the test tube and was shaken. Reading was taken from the spectrophotometer.

At $515 \mathrm{~nm}, 1 \mathrm{ml}$ of $\mathrm{Cd}-1,10 \mathrm{ml}$ of digested solution, $0.20 \mathrm{ml}$ of $\mathrm{Cd}-2$ reagent and 1 level green spoon of $\mathrm{Cd}-3$ were added in the test tube and shaken well. Reading was displayed on the Spectrophotometer.

At $540 \mathrm{~nm} \mathrm{pH}$ of the sample was checked, specified range: $\mathrm{pH} 1-9$. To adjust $\mathrm{pH}$ dilute sodium hydroxide solution or sulfuric acid was added drop by drop. In a dry test tube 1 level grey micro spoon of $\mathrm{Cr}-1$ and 6 drops of $\mathrm{Cr}-2$ was added. Test tube was shaken vigorously to dissolve solid substances. $5.0 \mathrm{ml}$ of sample was also pipette out and was mixed. Reaction time was one minute. After reaction time the solution was transferred into a corresponding cell. Method was selected with auto selector. Cell was placed into the cell compartment and the value on the display was noted [20, 21].

\section{3. $\mathrm{SO}_{X}, \mathrm{NO}_{X}, \mathrm{CO}_{2}, \mathrm{PM}_{10}, \mathrm{CO}, \mathrm{O}_{2}, \mathrm{VOC}_{S}$ Monitoring in Ambient Air}

\subsection{1. $\mathrm{NO}_{2}$ Monitoring of Ambient Air by Respirable Dust Sampler}

$25 \mathrm{ml}$ of $\mathrm{NO}_{2}$ absorption solution was taken in the impinger tube and was connected to the sampling train. Air was passed for 30 minutes. After passing air the sample was shifted to the ice box. At $540 \mathrm{~nm}$ absorbance was observed in $25 \mathrm{ml}$ cell against absorption solution.

\subsection{2. $\mathrm{SO}_{2}$ monitoring of Ambient Air by Respirable Dust Sampler}

$10 \mathrm{ml}$ of $\mathrm{SO}_{2}$ absorption solution was taken in the impinger tube and was connected to the sampling train. Air was passed for 30 minutes. After passing the air, absorbed solution was transferred in the amber plastic bottle. In laboratory the sample was placed in $25 \mathrm{ml}$ measuring flask along with the $1 \mathrm{ml}$ of sulfanilic acid and was leaved for 10 
minutes. $2 \mathrm{ml}$ of formaldehyde solution, $5 \mathrm{ml}$ pararosaniline reagent was added to make up the volume to $25 \mathrm{ml}$ with the distilled water. At $540 \mathrm{~nm}$ absorbance was measured against distilled water.

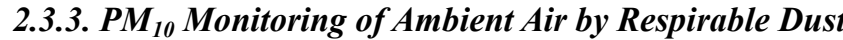 Sampler}

Glass fiber filter paper was weighed and placed in the high volume Respirable dust sampler. Air was passed for 1 hour. Filter paper was replaced. In laboratory filter paper was again weighed and results were calculated.

\subsubsection{Monitoring of $\mathrm{CO}, \mathrm{O}_{2}, \mathrm{VOC}_{S}$ of Ambient Air by VOC Meter}

Entry Rae system PGM-3000 was used to determine CO, $\mathrm{O}_{2}$ and $\mathrm{VOC}_{\mathrm{S}}$ in ambient air. Instrument was $\mathrm{ON}$. Reading was displayed on screen and was noted.

\subsubsection{Monitoring of $\mathrm{CO}_{2}$ of Ambient Air by $\mathrm{CO}_{2}$ Meter}

$\mathrm{CO}_{2}$ meter was used to determine $\mathrm{CO}_{2}$ in ambient air. Instrument was ON. Reading was displayed on screen and was noted.

\subsection{Monitoring of Stack emissions $\left(\mathrm{SO}_{X}, \mathrm{NO} \mathrm{O}_{X}\right.$ and CO by Flue Gas Analyzer}

Testo 350-S Flue gas analyzer was used to determine stack emission gases. It has a pump that draws gases from the stack with the help of a probe. This probe is inserted into the stack for the collection of gas sample. Reading was displayed on screen of analyzer and was noted.

\subsubsection{Monitoring of VOC in Stack emissions by VOC Meter}

Entry Rae system PGM -3000 was used to determine $\mathrm{VOC}_{\mathrm{S}}$ in stack emission. Instrument was ON. Reading was displayed on screen and was noted.

\section{Results and Discussion}

A1-Right side of the incinerator A2- Left side of the incinerator A3- Main Gate of the incinerator

\subsection{Results of Analysis of Ambient Air Monitoring (SOx, $\mathrm{NOx}, \mathrm{CO}, \mathrm{CO} 2, \mathrm{PM} \& \mathrm{O} 2)$}

Table 1. Results of Analysis of $\mathrm{SO}_{X}, \mathrm{NO}_{\mathrm{X}}$ and $\mathrm{PM}, \mathrm{O}_{2}$, VOCs, $\mathrm{CO} \& \mathrm{CO}_{2}$ Monitoring in Ambient air

\begin{tabular}{|c|c|c|c|c|c|c|}
\hline $\begin{array}{l}\text { Sr. } \\
\text { No }\end{array}$ & Parameter & Units & A1 & A2 & A3 & NAAQS \\
\hline 1 & $\mathrm{SO}_{\mathrm{X}}$ & $\mu g / m^{3}$ & 3.1 & 3.2 & 4.5 & 120 \\
\hline 2 & $\mathrm{NO}_{\mathrm{X}}$ & $\mu g / m^{3}$ & 35.6 & 32.5 & 46.2 & 40 \\
\hline 3 & PM & $\mu g / m^{3}$ & 137.8 & 135.5 & 140.8 & 150 \\
\hline 4 & $\mathrm{O}_{2}$ & $\%$ & 20.9 & 20.5 & 20.5 & \\
\hline 5 & $\mathrm{VOC}_{\mathrm{S}}$ & ppm & 1 & 2 & 1 & \\
\hline 6 & $\mathrm{CO}$ & ppm & 0 & 15 & 0 & \\
\hline 7 & $\mathrm{CO}_{2}$ & ppm & 382 & 416 & 434 & \\
\hline
\end{tabular}

Table 2. Results of Analysis of Monitoring of stack emissions (SOx, NOx, $\mathrm{CO}$ and $\mathrm{VOCs}$

\begin{tabular}{ccccc}
\hline Sr.No & Parameter & Units & Value & NEQS \\
\hline 1 & $\mathrm{SO}_{\mathrm{X}}$ & $\mathrm{mg} / \mathrm{Nm}^{3}$ & 7 & 1700 \\
2 & $\mathrm{NO}_{\mathrm{X}}$ & $\mathrm{mg} / \mathrm{Nm}^{3}$ & 17 & 400 \\
3 & $\mathrm{CO}$ & $\mathrm{mg} / \mathrm{Nm}^{3}$ & 149 & 800 \\
4 & $\mathrm{VOCs}$ & $\mathrm{ppm}$ & 1 & ---- \\
\hline
\end{tabular}

Table. 3 Results of Analysis of Heavy metal in fly and bottom ash (BDL= Below Detection Limit

\begin{tabular}{cccc}
\hline Sample & $\begin{array}{c}\mathbf{C d} \\
(\mathbf{m g} / \mathbf{k g})\end{array}$ & $\begin{array}{c}\mathbf{C r} \\
(\mathbf{m g} / \mathbf{k g})\end{array}$ & $\begin{array}{c}\mathbf{P b} \\
(\mathbf{m g} / \mathbf{k g})\end{array}$ \\
\hline Bottom Ash & $\mathrm{BDL}$ & $\mathrm{BDL}$ & $\mathrm{BDL}$ \\
Fly Ash & $\mathrm{BDL}$ & 1.96 & $\mathrm{BDL}$ \\
\hline
\end{tabular}

Emissions of $\mathrm{SO}_{\mathrm{X}}, \mathrm{NO}_{\mathrm{X}}, \mathrm{PM}_{10}, \mathrm{O}_{2}, \mathrm{VOC}_{\mathrm{S}}, \mathrm{CO}, \mathrm{CO}_{2}$ were the parameters considered for ambient air monitoring.

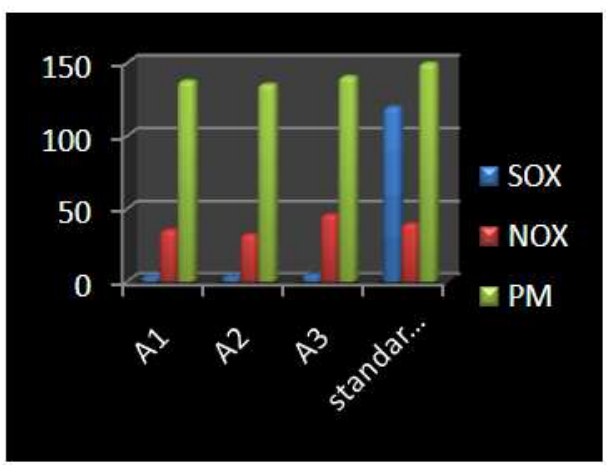

Figure 1. Comparison of $S O_{X}, N O_{X}$ and PM Monitoring results of Ambient air of incinerator

The result shown in "Fig.1" depicts that the emission concentration of $\mathrm{NO}_{\mathrm{X}}$ at $\mathrm{A} 3$ was higher than National Ambient Air Quality Standards. Emissions of $\mathrm{PM}_{10}$ were also comparatively higher than $\mathrm{SO}_{\mathrm{X}}$ and $\mathrm{NO}_{\mathrm{X}}$ in all the three areas i-e A1, A2 and A3. Comparison of these results with Air Quality Index (AQI) cleared the picture of $\mathrm{PM}_{10}$. It can be clearly interpreted that the emissions from the incineration plant were not under compliance, as the AQI has termed emissions between $101-150 \mu \mathrm{g} / \mathrm{m}^{3}$ to be unhealthy in the Area 3 (A3) as compared to A1 and A2 [22, 23].

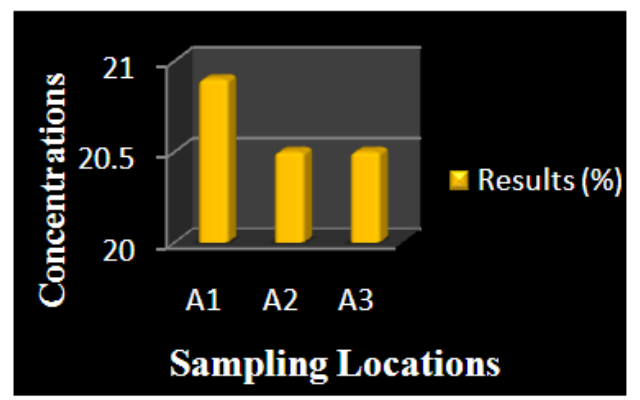

Figure 2. Comparison of $\mathrm{O}_{2}$ Monitoring results of Ambient Air of incinerator 
"Fig. 2" shows that the Oxygen $\left(\mathrm{O}_{2}\right)$ level was same at $\mathrm{A} 2$ and $\mathrm{A} 3$ of the incinerator.

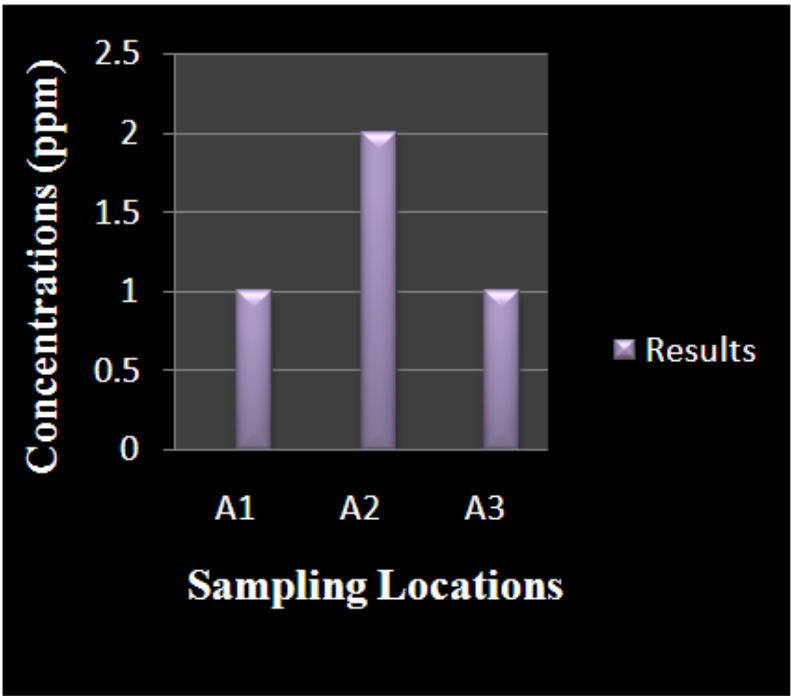

Figure 3. Comparison of $V O C_{S}$ Monitoring results of Ambient Air of incinerator

Volatile organic compounds $\left(\mathrm{VOC}_{\mathrm{S}}\right)$ are the gases that result from solid and liquid waste. "Fig. 3" shows the comparison of $\mathrm{VOC}_{\mathrm{S}}$ emissions at all three areas of the incinerator considered. The results revealed that the concentration of $\mathrm{VOC}_{\mathrm{S}}$ were significantly higher in the area 2 whereas the $\mathrm{VOC}_{\mathrm{S}}$ concentrations in the A1 and A3 were observed to be same i-e $1 \mathrm{ppm}$.

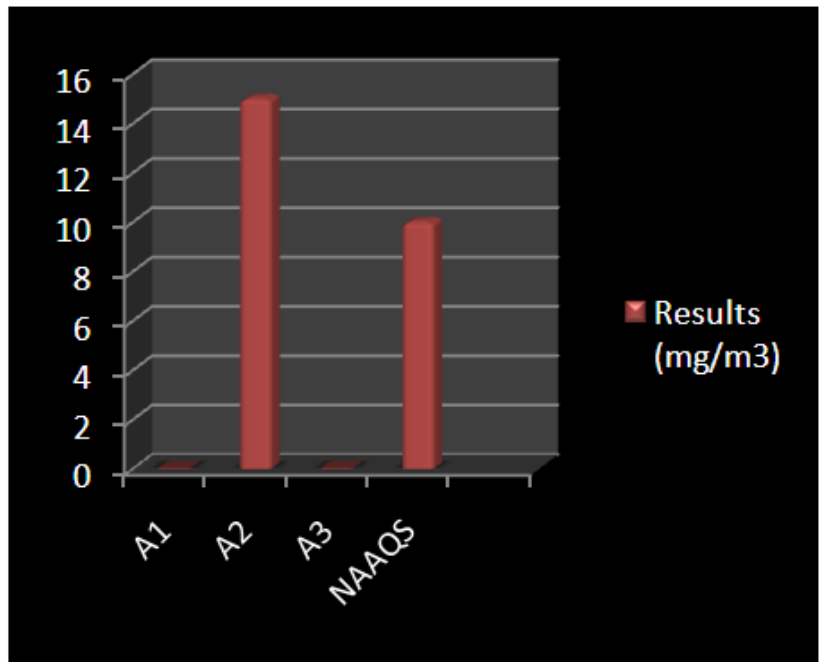

Figure 4. Comparison of $\mathrm{CO}$ Monitoring results of Ambient Air of incinerator with $N A A Q s$

Carbon monoxide (CO) which is the toxic and poisonous gas may result from incomplete combustion of fossil fuels, was also monitored for ambient air quality. The results of CO monitoring represented in the "Fig. 4" shows that the concentration of $\mathrm{CO}$ emissions in $\mathrm{A} 2$ were highest whereas no $\mathrm{CO}$ emissions were witnessed at $\mathrm{A} 1$ and $\mathrm{A} 3$. Emissions at A2 were also not complying with National Ambient Air Quality Standards [22].

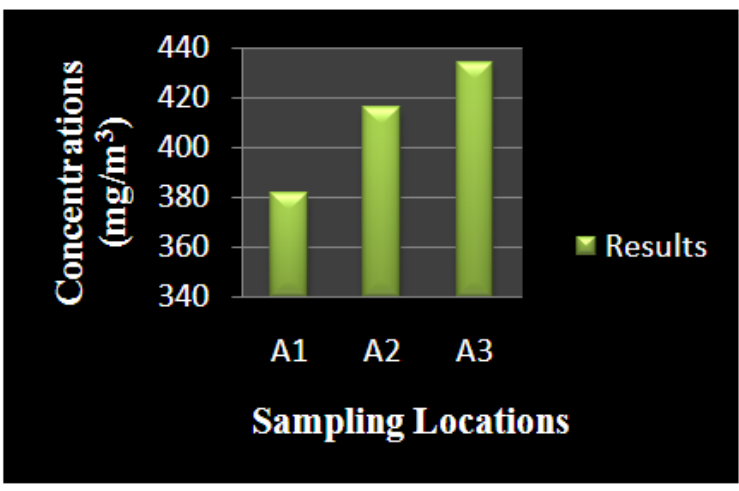

Figure 5. Comparison of $\mathrm{CO}_{2}$ Monitoring results of Ambient Air of incinerator

$\mathrm{CO}_{2}$ concentration was also monitored in ambient air quality. "Fig. 5" shows that the emission concentration of $\mathrm{CO}_{2}$ at the main gate of the incinerator (A3) was significantly higher than emissions from the right (A1) and left side (A2) of the incinerator.

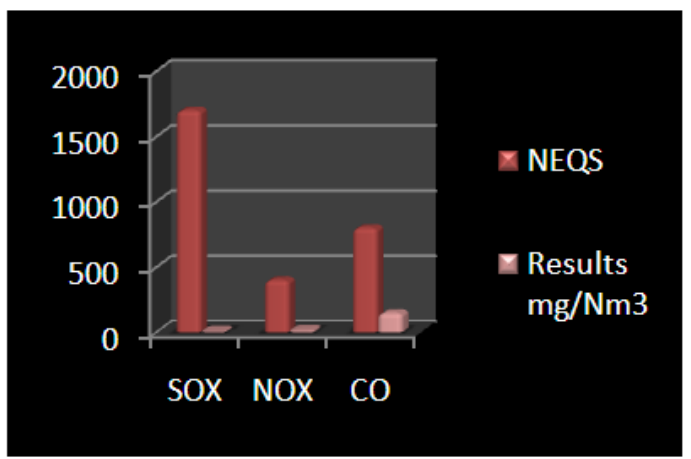

Figure 6. Comparison of $\mathrm{SO}_{X}, N \mathrm{~N}_{X}$ and $\mathrm{CO}$ monitoring results of stack emissions of incinerator with NEQS

For the purpose of stack emissions $\mathrm{SO}_{\mathrm{X}}, \mathrm{NO}_{\mathrm{X}}$ and $\mathrm{CO}$ were monitored with the help of flue gas analyzer. "Fig. 6" shows that the concentration of $\mathrm{CO}$ in the stack was higher as compared to the concentrations of $\mathrm{SO}_{\mathrm{X}}$ and $\mathrm{NO}_{\mathrm{X}}$ [22].

$\mathrm{VOC}_{\mathrm{S}}$ were also monitored in stack emissions. "Table 2" shows the concentration of $\mathrm{VOC}_{\mathrm{S}}$ in the stack emissions. They were observed to be very low in amount. All selected parameters studied for stack emissions showed that they were under compliance with their respective standards.

Fly and Bottom ash are the solid output of incineration process. They contain significant amount of heavy metals. "Table. 3" shows that the amounts of heavy metals $(\mathrm{Cd}, \mathrm{Pb}$ and $\mathrm{Cr}$ ) in bottom ash were below the detectable limits (BDL), whereas heavy metals $\mathrm{Cd}$, and $\mathrm{Pb}$ in Fly ash were also below the detectable limits except chromium which was $1.96 \mathrm{mg} / \mathrm{kg}$.

\section{Conclusion and Recommendations}

The ambient air quality was monitored at three different sides of the incinerator. The results showed that the emissions at left side of the incinerator and main gate of the 
incinerator were significantly higher than the emissions at right side of the incinerator. Stack emissions monitoring results revealed that the concentration of carbon monoxide was higher than the concentration of SOX and NOX and VOCS. The analysis of heavy metals $(\mathrm{Cd}, \mathrm{Cr}$ and $\mathrm{Pb})$ in bottom ash revealed that their concentration was below the detectable limits. The examination of heavy metals $(\mathrm{Cd}, \mathrm{Cr}$ and $\mathrm{Pb}$ ) in fly ash confirmed that the $\mathrm{Pb}$ and $\mathrm{Cd}$ were below the detectable limits whereas the concentration of $\mathrm{Cr}$ was $1.96 \mathrm{mg} / \mathrm{kg}$.

Instead of incinerating massive quantities of organic wastes, it should be converted into compost or biofertilizers after necessary amendments.

Health and safety guidelines should be followed and personal protective equipments should be used by all the staff and visitors of the incinerator plant when it is under operation.

\section{References}

[1] O. Anubhav, C.B. Abhishek, S. Durgesh, "Solid waste management in developing countries through Plasma Arc Gasification,” APCBEES Procedia, 1, pp 193-198, 2012.

[2] TT. Eighmy, J.J. Dykstra Eusden, J.E. Krzanowski, et al., "Comprehensive approach toward understanding element speciation and leaching behavior in municipal solid waste incineration electrostratic precipitator ash," J. Sci Total Environ., 29, pp. 629-646, 1995.

[3] C. Ferreira, A. Ribeiro, L. Ottosen, "Possible applications for municipal solid waste fly ash," J. Hazard. Mater., 96, pp. 201-216, 2003

[4] D.J. Lisk, "Environmental Implications of incineration of municipal solid waste and disposal," J. Sci Total Environ., 74, pp. 39-66, 1988 .

[5] C.C. Travis, H.A. Hatterner -Frey, "Human exposure to dioxin,” J. Sci Total Environ., 104, pp. 97-127, 1991.

[6] P.A. Valberg, P.J. Drivas, S. McCarthy, A.Y Watson, "Evaluating the health impacts of incinerator emissions," J. Hazard. Mater., 47, pp. 205-227, 1996.

[7] S.J. Elliot, "A compartive analysis of public concern over solid waste incinerators," J. Waste Manage. Res., 16, pp. 351-364, 1998.

[8] G. Rice, J. Swartout, E. Brady Roberts, D. Reisman, K. Mahaffey, B. Layon, "Characterization of risks posed by combustor emissions," J. Drug Chem Toxicol., 22, pp. 221$240,1999$.

[9] J.M. Chimenos, M. Segarra, M.A. Fernandez, et al., "Characterization of the bottom ash in municipal solid waste incinerator,” J. Hazard. Mater., 64, pp. 211-222, 1999
[10] R. Klein, T. Baumann, E. Kahapka, et al., "Temperature development in a modern municipal solid waste incineration (MSWI) bottom ash landfill with regard to sustainable waste management," J. Hazard. Mater., 83, pp. 265-280 , 2001.

[11] S.E. Sawell, A.J. Chandler, T.T. Eighmy, et al., "An international perspective on the characterisation and management of residues from MSW incinerators," J. Biomass Bioenergy, 9,pp. 377-386, 1995.

[12] H.A. Van der Sloot, D.S. Kosson, Hjelmar, "Characteristics, treatment and utilization of residues from municipal waste incineration,” J. Waste Manage., 21, pp. 753-765, 2001

[13] S. Gau, W. Jeng, "Influence of ligands on metals leachability from landfilling bottom ashes," J. Hazard. Mater., 58, pp. 59-71,1998.

[14] C.H. Jung, T. Matsuto, N. Tanaka, et al., "Metal distribution in incineration residues of municipal solid waste (MSW) in Japan, ”J. Waste Manage., 24, pp. 381-391, 2004.

[15] E.E. Chang, P.C. Chiang, P.H. Lu, et al., "Comparisons of metal leachability for various wastes by extraction and leaching methods, " Chemosphere, 45, pp. 91-99, 2001.

[16] V. Bruder-Hubscher, F. Lagarde, M.J.F Leroy,-et al., "Application of a sequential extraction procedure to study the release of elements from municipal solid waste incineration bottom ash, " J. Anal Chim Acta , 451, pp. 285-295

[17] C.M. Radetski, B. Ferrari, S. Cotelle, et al., "Evaluation of the genotoxic, mutagenic and oxidant stress potentials of municipal solid waste incinerator bottom ash leachates," J. Sci Total Environ., 333, pp. 209-216, 2004.

[18] K.W. Schramm, A. Hofmaier, O. Klobasa, et al., "Biological in vitro emission control,” J. Anal. Appl. Pyro., 49, pp. 199 210,1999

[19] GEL.www.gel.com.pk/waste.html. Accessed on November 102012

[20] http://www.cropwat.agrif.bg.ac.rs/content/files/laboratory\% 20 manual $\% 20$

$\% 20$ Photometric $\% 20$ methods $\% 20$ for $\% 20$ determination $\% 20$ of $\% 20$ chemical $\% 20$ contaminants $\% 20$ in $\% 20$ water.pdf. Accessed on December 17, 2012

[21] https://www.google.com.pk/url?sa=t\&rct=j\&q=\&esrc=s\&so urce $=$ web $\&$ cd $=2 \&$ cad $=$ rja \&ved $=0 \mathrm{CDAQFjAB \& url}=\mathrm{http} \% 3$ A $\% 2$ F\% $\%$ Fwww.hach.com\%2Fassetget.download.jsa\%3Fid\%3D7639983705\&ei=xQQFUpyxAt Lh4AOHoIGQBQ\&usg=AFQjCNGNnxXYwa8bMz2HX4 X0IeM08LJTOA\&bvm=bv.50500085,d.dmg. Accessed on December 17, 2012

[22] http://www.broward.org/POLLUTIONPREVENTION/AIR QUALITY/Pages/CriteriaAirPollutants.aspx. Accessed on December 20, 2012

[23] http://www.hcdoes.org/airquality/monitoring/pm.htm. Accessed on January 15, 2013. 